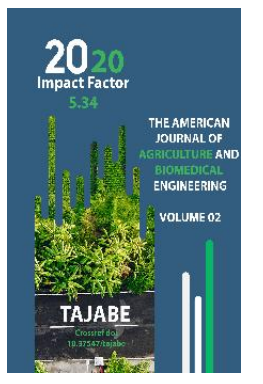

Journal Website: http://usajournalshub.c om/index,php/tajabe

Copyright: Original content from this work may be used under the terms of the creative commons attributes 4.0 licence.

\section{Biological Efficiency Of Fungal Insecticides Against Swarming Locusts In Uzbekistan}

\author{
Tufliyev N.Kh. \\ Department Of Plant Protection, Tashkent State Agrarian University, Tashkent, Uzbekistan.
}

Usmanov S.P.

Andijan branch of Tashkent State Agrarian University, Andijan, Uzbekistan

Gapparov F.A.

Department Of Plant Protection, Tashkent State Agrarian University, Tashkent, Uzbekistan.

Nurjonov F.A.

Department Of Plant Protection, Tashkent State Agrarian University, Tashkent, Uzbekistan.

Abdalyazov N.A.

Academy Of Mamun, Khiva, Uzbekistan.

\title{
ABSTRACT
}

The article presents the results of experiments which provided to definite of biological efficacy of the microbial insecticides "Kiloca", "Fast Kiloca" and Green Guard SC based on the fungi Metarrhizium anisoplia (Metsch.) against Moroccan locust (Dociostaurus Maroccanus Thunb.). Experiments have been provided at the laboratory condition of the laboratory "Researching and control of pasture pests" of Uzbek research institute for Plant protection. To provide experiments locusts has been collected from pastures of Guzar and Nishan provinces of Kashkhadarya region of the Republic of Uzbekistan.

\section{KEYWORDS}

Pasture pests, Dociostaurus Maroccanus Thunb., locust control, microbial insecticides, fungal insecticide, microbial control of locusts, Metarrhizium anisoplia (Metsch.)

\section{INTRODUCTION}

In the world, harmful locusts require constant attention from industry experts. Only in the countries of the Caucasus and Central Asia, failure to control harmful herd locusts, such as Moroccan, Italian and Asian locusts, by causing damage to pasture lands on an area of more than 25 million hectares, as well as agricultural crops, leads to loss of received from them products. As a result, more than 20 million people could left without agricultural products.

The development and improvement of evidence-based control measures against 
these pests and their timely implementation in foothill, pasture and steppe zones is one of the most important tasks of almost all countries of the world where locusts are common. In particular, studies have conducted in the United States, Europe, Australia, China, the CIS countries, Africa and various regions of other Asian countries where harmful locusts are common. However, studies on the creation of conditions for microbiological control of harmful locusts, the creation of a complex for the application of modern methods and means against them, the determination of the causes of the spread of non-herd locust crops around crops, and the development of effective control measures against them.

In the Republic of Uzbekistan, some types of harmful locusts are dangerous not only for pasture plants, but also for all crops. To constantly ensure, the needs of the population in dairy and meat products, an important task is to protect the vegetation of foothill, pasture and steppe zones from harmful locusts. The Development Strategy of the Republic of Uzbekistan in 2017-2021 noted that the priority tasks of agriculture are "the development and implementation of measures to protect plants from diseases and pests." In this regard, in order to prevent mass reproduction and create a danger to crops, it is necessary to identify the main harmful species of locusts found in the foothills, pasture and steppe zones, study the features of their development, as well as create and implement a set of effective, environmentally friendly measures and means.

Currently, the focus in the control against pest locusts is the use and spread of ecologically safe microbial pesticides. In particular, it has been studied that the microbial pesticides of Green Guard SC Premium against moroccan locust and Italian locust (Calliptamus italicus L.) has a biological effect controlled near 80.0\%, this is effectively score in Uzbekistan and Georgia $[1,4,5]$.

\section{MATERIALS AND METHODS}

The microbial insecticide Kiloca based on the fungi Metarrhizium anisopliae, made in China Xin Jiang MOER Chemscience Co., Ltd. Titer of the insecticide is $1: 20 \times 108$. Consumption rate is $1,0-1,5 \mathrm{l} / \mathrm{h}$. The second microbial insecticide is "Fast Kiloca", which produced in China Company Xin Jiang MOER Chemscience Co., Ltd. Difference between fast Kiloca from Kiloca is the chemical-acting compound betacypermetrhin in $1 \%$. Chemical substance betacypermetrhin belongs to the group of pyrethroids which an organic compound similar to the natural pyrethrins, which are produced by the flowers of pyrethrums (Chrysanthemum cinerariaefolium and C.coccineum). Betacypermetrhin increases the initial effect of this biopesticide.

The third microbial insecticide is Green Guard SC Premium based on the fungi Metarrhizium anisoplia also. The preparation is product of the company Becker Underood (BASF) Australia. This insecticide used as an etalon.

Experiments was carried out to research the biological effectiveness of microbial insecticides based on the fungi Metarrhizium anisoplia in the laboratory condition against Moroccan locust (Dociostaurus maroccanus Thunb.), which is the main gregarious locust widespread in the Republic of Uzbekistan.

Researching of the biological efficacy of microbial insecticide used in experiments was calculated by Dospekhov's [2] method. Make a dispersion analysis of the results of the conducted experiments by the Kurdyukov's method [3]. 
Experiments were conducted on the creation of natural conditions for locusts in specially made cages. On average, each of cage put 3040 nymphs of healthy II-III instar Moroccan locusts. For the template, the Green Guard SC$0,5 \mathrm{l} / \mathrm{ha}$ biopesticide was used (fig.3).

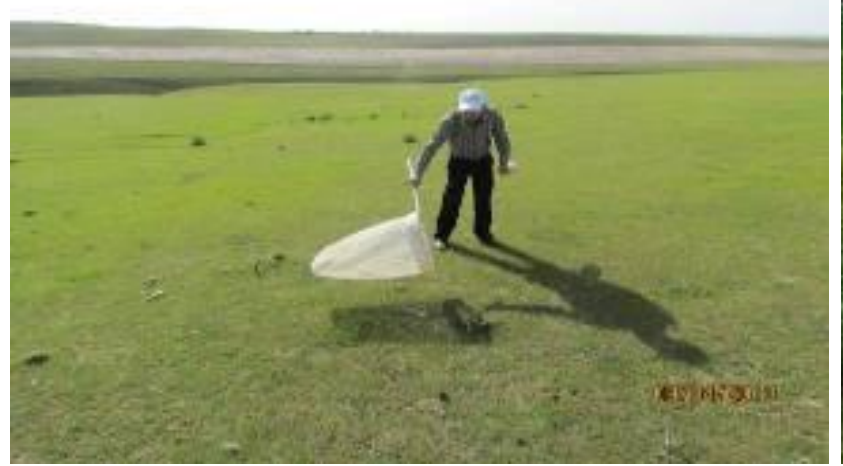

Fig. 1. Collection of samples from locust outbreaks

\section{RESULTS}

In experiments with Kiloca with consumption rate 1,0 I/ha, two days after spraying, the monitoring showed the 52,1 percent biological effectiveness. After 4 days get $55,3 \%$, on 6 day $62,5 \%$, on 8 day $69,7 \%$, and on 21 day $83,4 \%$ biological efficiency. In the second variant, which spraying Kiloca with consumption rate $1,5 \mathrm{l} / \mathrm{ha}$, the calculating shows $64,6 \%$ biological efficiency on the 2 nd day of experiment. $71,8 \%$
During the accounting period of our experiments, temperature was also monitored and the average temperature was 28-300C.

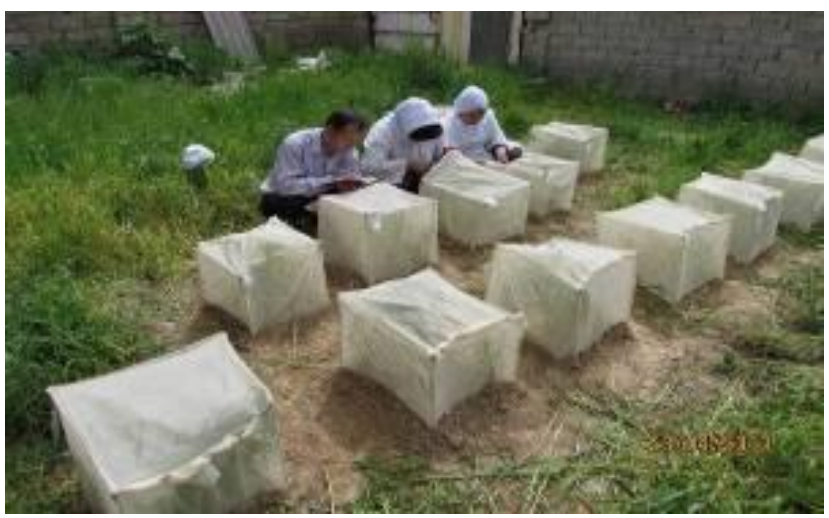

Fig. 2. Special cages were used for small laboratory experiments.

on the 4th day, $74,0 \%$ on the 6 th day and $75,0 \%$ on the 8th day, accordingly. In the variant applied to the Green Guard SC-0,5 I/ha, it was found that the checking showed $29,6 \%$ of biological efficiency on the 2nd day of spraying, $36 \%$ on the 4 th day, $41,0 \%$ on the 6 day, $45,7 \%$ on the 8 th day and $92,0 \% 32$ days after treatment (Fig.3). 


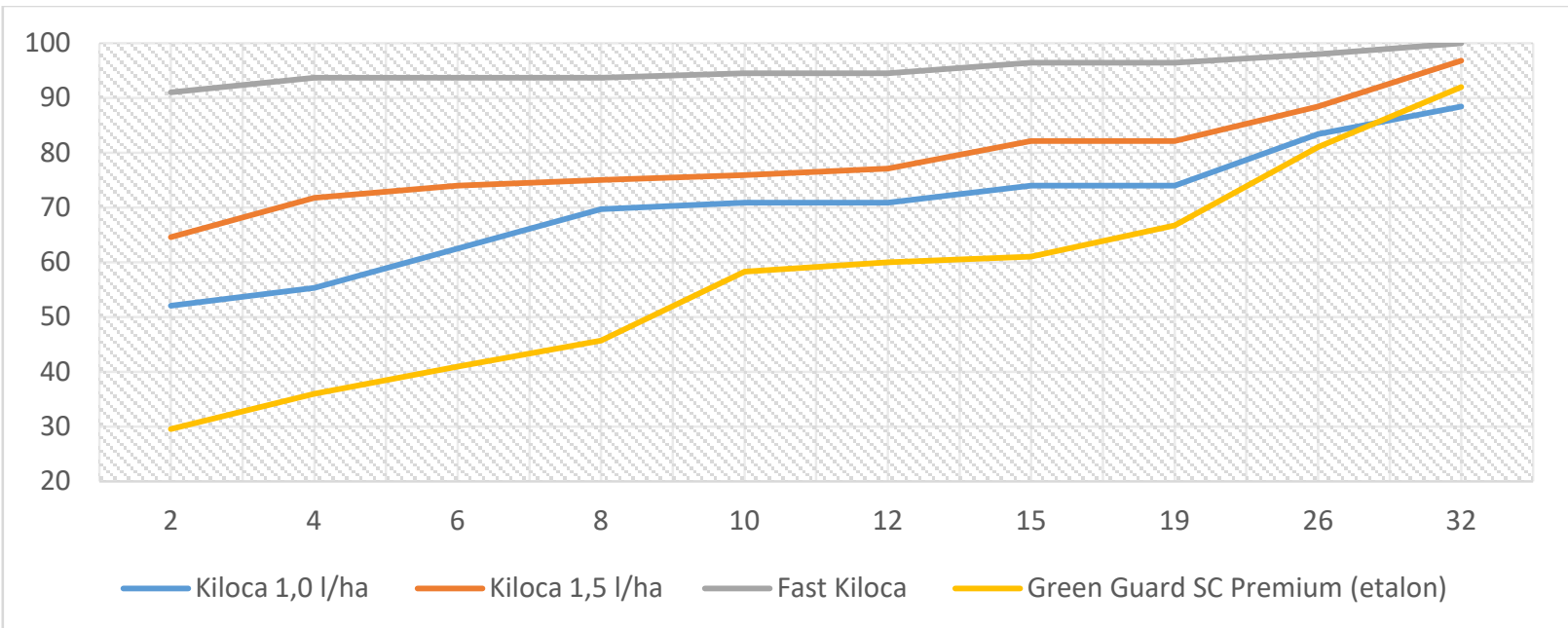

Fig. 3.

Biological efficacy of microbial pesticides based on the fungi Metarrhizium anisopliae against Moroccan locust (Dociostaurus maroccanus) nymphs.

* Kiloca (Metarrhizium anisopliae) Xin Jiang MOER Chemscience Co., China. Ltd.,

Fast Kiloca (Metarrhizium anisopliae $+1 \%$ betacypermetrhin) Xin Jiang MOER Chemscience Co., China. Ltd.,

Green Guard SC (Metarrhizium anisopliae var. acridum) Becker Underood (BASF), Australia Ltd.

The experiment with pesticide sprayed with a chemical component Betacypermetrhin - Fast Kiloca 1,0 I/ha pesticide, the counting was showed 91,0 percent of biological effectiveness on the 2nd day of the experiment. On the fourth day $93,7 \%$ and 6,8 , 10 days after treatment we get $93,7 \%-93,7 \%$ $94,5 \%$ biological efficiency, accordingly. It gained $98,0 \%$ biological efficiency in 26 days, $100 \%$ in 32 days.

The Green Guard SC Premium with consumption rate $0,5 \mathrm{l} / \mathrm{ha}$ which used as an etalon has showed $26,6 \%$ biological efficiency on the 2 nd day of the experiment, $35,6 \%$ on the 4 th day, $40,0 \%$ on the 6 th day, and $91,0 \%$ on the 32 day of the experiment (Fig.3).

\section{CONCLUSIONS}

According to the results of the experiment, the maximum biological effect of using microbial insecticide Kiloca at $1.0 \mathrm{I} / \mathrm{ha}$ to control Moroccan locust nymphs was $83.4 \%$, with the highest biological efficiency of 1.5 I/ha. was $96,8 \%$.

Fast Kiloca also records the highest $100.0 \%$ bioefficiency of microbiological and chemical pesticides at $1.0 \mathrm{l} / \mathrm{ha}$ to accelerate initial effects to improve microbial biopesticides effects.

After provided experiments of Kiloca-1.0-1.5 I/ha and Fast Kiloca-1.0 I/ha, it has been recommended to use these microbial insecticides against gregarious locust for saving ecological environment in Uzbekistan. 


\section{REFERENCES}

1. Gapparov F.A., Nurzhanov A.A., Tufliyev N.Kh., Agzamova Kh.K., Medetov M. New biological preparations against pests in Uzbekistan. // Journal of Plant Protection and Quarantine. - Moscow, 2013 - No. 6. P. 28.

2. Dospekhov B.A. Field experiment technique. - M.: Agropromizdat, 1985.$432 \mathrm{p}$.

3. Kurdyukov V.V., Khodjaev Sh.T., Gapparov F.A. Harmful locusts // Guidelines for testing insecticides, acaricides, biologically active substances and fungicides. -Tashkent:

Uzinformagroprom, 1994. - P. 18-20.

4. Tufliev N.Kh. Creation of a complex for the fight against harmful locusts in the foothill, pasture and steppe zones of Uzbekistan, author's abstract of the dissertation of a doctor (dsc) of agricultural sciences. 06.01.09. - Tashkent, 2019.- 69 p. (Uzbek, Russian language).

5. Hunter D.M., Latchininsky A.V., Abashidze E., Gapparov F.A., Nurzhanov A.A., Tufliev N.Kh., Medetov M.Z. The efficacy of Metarhizium acridum against nymphs of the Italian locust, Calliptamus italicus (L.) (Orthoptera:Acrididae) in Uzbekistan and Georgia. //Journal of Orthoptera Research. - USA, 2016. - Volume 25(2): P. 61-65.

6. Sali, Y.S., Nong, X.Q., Wang, W.F., Sidike, AL.M., Zhang, Z.H. Evaluation for Virulence and Potential Application of Metarhizium Strains against Tibet Migratory Locusts: Locusta migratoria tibetensis Chen (Orthoptera, Acridoidea). I 11th international Congress of Orthopterology, Orthoptera in scientific progress and human culture Abstract \& Program. 11th-15th, Aug, 2013. Kunming, China. - P. 168. 